\title{
O nurcie białoruskim w polskiej prozie emigracyjnej ${ }^{1}$
}

\author{
On the Belarusian trend in the Polish \\ emigration prose
}

\author{
|Tadeusz Sucharski
Akademia Pomorska w Słupsku
}

\begin{abstract}
The aim of this paper is to distinguish an important trend of memoir literature in the Polish emigration prose. The trend of "returning to small homelands", very important in the post-war Polish literature, resulted in many memoirs. The most important works were devoted to the lands of Ukraina and Belarusia. However, memories and novels devoted to life in the Belorussian territories usually are included in the Lithuanian trend because of their historic affiliation to the Grand Duchy of Lithuania. The presented paper is an attempt to establish the proper hierarchy. The author of the text is interested in devoting the importance of the Belarusian culture to the Polish emigration literature, he is also interested in revealing the awakening of the Belarusian national identity. For the tension between Polishness and Belarusianness plays an important role in the Belarusian trend. And this aspect cannot be lost in reflections on the literary memories of Polish life in the Belorussian territories.
\end{abstract}

Key words: emigration literature, trend of "returning to small homelands”, national identity, Polishness

Streszczenie: Celem prezentowanego szkicu jest dostrzeżenie i wyróżnienie bardzo ważnego nurtu w polskiej powojennej prozie emigracyjnej. Nurt „powrotu do małych ojczyzn", bardzo istotny w polskiej prozie powojennej, zaowocował wieloma dziełami wspomnieniowymi. Najważniejsze z nich poświęcone zostały ziemiom ukraińskim i białoruskim. Wspomnienia i powieści na temat życia na ziemiach białoruskich włączane są zwykle do nurtu litewskiego z powodu ich historycznej przynależności do Wielkiego Księstwa Litewskiego. Prezentowany szkic stanowi próbę ustanowienia właściwej hierarchii. Autorowi tekstu zależy na oddaniu ważności kultury białoruskiej dla polskiej literatury emigracyjnej, ale także na ujawnieniu budzenia się białoruskiej tożsamości narodowej.

\footnotetext{
${ }^{1}$ Publikowany artykuł to znacznie skrócona wersja szkicu Między dwiema liniami Curzona, czyli Białoruś w polskiej prozy emigracyjnej, w: Pogranicza, Kresy, Wschód a idee Europy, idea i wstęp J. Ławski red. naukowa A. Janicka, G. Kowalski, Ł. Zabielski, Seria I: Prace dedykowane Profesor Swietłanie Musijenko, Białystok 2013, s. 463-492.

The published article is a much shortened version of the sketch Between the two Curzon's lines, that is Belarus in Polish emigration prose, in: Pogranicza, Kresy, Wschód a idee Europy, idea and introduction J. Ławski, ed. A. Janicka, G. Kowalski, Ł. Zabielski , Seria I: Prace dedykowane Profesor Swietłanie Musijenko, Białystok 2013, pp. 463-492.
} 
Albowiem w nurcie białoruskim napięcie między polskością i białorosyjskością odgrywa ważną rolę. I ten aspekt nie może zaginąć w refleksjach nad literackimi wspomnieniami polskiego życia na ziemiach białoruskich.

Słowa kluczowe: literatura emigracyjna, nurt „powrotu do małych ojczyzn”, tożsamość narodowa, polskość

W powstałym ponad trzydzieści lat temu szkicu Nina Taylor-Terlecka podjęła próbę pierwszego, „konspektowego” ujęcia problemu „dziedzictwa W. X. Litewskiego" w literaturze emigracyjnej (Taylor-Terlecka 1986, 124). Króciutki przegląd żołniersko-nostalgicznej poezji „litewskiej” stał się właściwie uwerturą do refleksji nad powieścią „litewską”, którą - jak dowodzi autorka - tworzyli Florian Czarnyszewicz, Sergiusz Piasecki, Józef Mackiewicz i Czesław Miłosz. Autorka szkicu z pełną świadomością podkreśla, że używany przez nią przymiotnik „litewski” w sensie historycznym „nie oddaje sprawiedliwości wkładowi kultury białoruskiej” (Taylor-Terlecka 1986, 125). Wydaje się, że przyszedł czas, by tę sprawiedliwość oddać. Należy wreszcie w „dziedzictwie W. X. Litewskiego” oddzielić nurt litewski od znacznie bogatszego nurtu białoruskiego. Jak rozumieć ów nurt? Wyodrębnienie „szkoły litewskiej” wynikało z automatycznego powiązania problematyki dzieła z Wielkim Księstwem jako swoistym i ugruntowanym już w literaturze genius loci, jako jedyną i niepowtarzalną przestrzenią. Taki najprostszy schemat można również zastosować do nurtu białoruskiego ${ }^{2}$, należałoby go jednak w taki sposób poszerzyć, by uwzględnić, mówiąc słowami Józefa Mackiewicza, pełnię tamtejszego „pejzażu”. A więc „i powietrze, lasy, i pola, i błota i człowieka jako część składową" (Mackiewicz 1994, 407). Samo miejsce akcji nie wydaje się bowiem wystarczającym wyróżnikiem nurtu (dlatego należy z niego wyeliminować powieści Piaseckiego). Ważne są utwory, w których uwzględniona została, choćby w pewnym stopniu, specyfika owego niezwykłego „pejzażu”, a więc wielonarodowość, wielowyznaniowość, wielokulturowość oraz relacje między różnymi społecznościami zamieszkującymi go. Przyjęcie takich kryteriów oznacza niewątpliwie przekroczenie obowiązującego nieprzerwanie spojrzenia historycznego, ale pozwala przywrócić jeśli nie należną hierarchię, to na pewno równowagę między litewskością i białoruskością, jako składowymi elementami polskiego piśmiennictwa emigracyjnego (choć także i krajowego ${ }^{3}$ ) związanego tematycznie z Wielkim Księstwem. I do tak wyodrębnionego nurtu włączyć znacznie większą grupę pisarzy. Bo jeśli Mackiewicza i Miłosza (jako autora esejów z tomu Szukanie ojczyzny) można zaliczyć także do szkoły białoruskiej, to nie dałoby się zastosować odwrotnego procederu

\footnotetext{
${ }^{2} \mathrm{O}$ „szkole białoruskiej” w literaturze romantycznej pisał Jackiewicz M., 1996, „Szkoła białoruska” w polskiej literaturze romantycznej, „Acta Polono-Ruthenica” I, s. 113-121.

${ }^{3}$ W literaturze krajowej nurt białoruski reprezentują m. in.: Aleksander Jurewicz (Lida; Pan Bóg nie słyszy głuchych; Prawdziwa ballada o miłości; Dzień przed końcem świata); Zbigniew Żakiewicz (Ród Abaczów; Dolina Hortensji, Wilcze łąki), Tadeusz Konwicki (Bohiń).
} 
(czyli włączenia do nurtu litewskiego) z Florianem Czarnyszewiczem głębinowo zanurzonym w świecie polsko-białoruskim.

Taylor-Terlecka wspomniała w eseju także o twórczości Zofii Bohdanowiczowej, Michała K. Pawlikowskiego i Wiktora Trościanki, pozostawiając ją świadomie do późniejszej refleksji. Z perspektywy „nurtu białoruskiego" taki repertuar nazwisk oznacza drastyczne jego zubożenie o utwory ważne, a nawet bardzo ważne. Trzeba tu jeszcze dodać Marię Czapską, Franciszka Wysłoucha, a także Marię Kuncewiczową jako autorkę Leśnika. Musi się także znaleźć Wacław Lednicki jako autor Pamiętników, których znaczenie dla białoruskiego tematu najpełniej wyraziła Czapska, podkreślając: „o ile ktoś zapyta o Białoruś w początkach XX wieku (...), świadomy rzeczy historyk odpowie: «Czytaj Lednickiego»!" (Czapska 2006, 163).

Białoruski nurt $\mathrm{w}$ piśmiennictwie emigracyjnym otwierają niezwykle mocnym akordem Nadberezyńcy Floriana Czarnyszewicza. Ustalają arcywzorzec, któremu nie sprosta już żaden inny utwór. Powieść, powstała z „rozmyślania tęsknego o ziemicy rodzonej” (Czarnyszewicz 1991, 281), rozpoczęta została jeszcze przed wojną, w Argentynie, do której jej autor, jako „pasierb” Niepodległej, wyjechał „za chlebem” w roku 1924, i wydana w Buenos Aires już w 1942. Dla jej pierwszych, wojennych jeszcze czytelników, zwłaszcza tych ze wschodnich ziem II Rzeczypospolitej, była jak Pan Tadeusz dla Sienkiewiczowskiego latarnika, ale dawała jeszcze wtedy nadzieję, że wojenna tułaczka się skończy i wrócą do tej „ziemicy rodzonej”. Czarnyszewicz już takich nadziei nie miał. Po nadberezyńskiej epopei, po jedenastu latach przyszła jej bezpośrednia kontynuacja, powieść Wicik Żywica, wydana w roku 1953, również w Buenos Aires. Po kolejnej dekadzie opublikował w Londynie ostatnią powieść, powracając przed śmiercią do świata młodości, częściowo już tylko nadberezyńskiej, głównie jednak wileńskiej. Niemal równolegle z wydaniem Wicika Żywicy paryska „Kultura” wydrukowała w roku 1952 Leśnika Marii Kuncewiczowej, powieść niezwykle ważną w refleksji poświęconej relacjom polsko-białoruskim, poświęconą budzeniu się (i utracie) tożsamości i świadomości narodowej. Książkowe wydanie powieści miało już miejsce w Polsce w roku 1957, jej pierwodruk jednak ukazał się na emigracji. W połowie roku 1956 gotowa była też powieść (choć taka genologiczna specyfikacja z trudnością tylko odpowiada tej fabularyzowanej autobiografii) Dzieciństwo i młodość Tadeusza Irteńskiego Michała Kryspina Pawlikowskiego. Kolejne jej fragmenty publikowały londyńskie „Wiadomości” w latach 1957-1958 pod pierwotnym tytułem Bajka. Ów tytuł, nieco ironiczny, nieco nostalgiczny idealnie oddaje klimat życia rodziny ziemiańskiej w Mińszczyźnie, codzienność tej formacji w jej latach schyłkowych do roku 1914, który dla Pawlikowskiego stanowił prawdziwe zamknięcie XIX stulecia. Na książkowe wydanie czekała jednak Bajka aż do roku 1959, w którym opublikowano ją pod tytułem Dzieciństwo i młodość Tadeusza Irteńskiego. Po „bajce” przyszedł „dramat”, zasygnalizowany już w tytule. Otóż w roku 
1965 Instytut Literacki w Paryżu opublikował Wojnę i sezon, drugą część z zaplanowanej trylogii Pamiętnik emigracyjny Tadeusza Irteńskiego. Jej najbardziej interesujące fragmenty odtwarzają wojenno-rewolucyjną codzienność ziemiańskich dworów na ziemiach, w których autor umieszczał teatr zmagań dwóch cywilizacji. Konsekwencją owych zmagań okazało się pożegnanie z kilkuwiekową obecnością polskiej, a szerzej - zachodniej kultury na Mińszczyźnie. Równocześnie z Wojna i sezonem ukazały się dwa tomy bardzo obszernych Pamiętników Wacława Lednickiego. Podobne do książek Pawlikowskiego w założeniu kompozycyjnym, choć zupełnie różne genologicznie, były dwie wspomnieniowe książki Marii Czapskiej. W latach 60. „na paryskim bruku” odtworzyła w Europie w rodzinie losy swojej arcyeuropejskiej rodziny żyjącej na ziemiach mińskich. Książka wydana została w roku 1969. Czapska, nieco inaczej niż Pawlikowski, przeciągnęła historię rodziny zapoczątkowaną jeszcze w epoce przedrozbiorowej, przedbarskiej, aż po rozpad dotychczasowego porządku w roku 1917 i ostateczne pożegnanie z domem w roku 1920. Ale tematy, o których w Europie... zaledwie napomknęła, znalazły niezwykle interesujące rozwinięcie w późniejszym o kilka lat Czasie odmienionym. Pogłębiła Czapska wspomnienia refleksją nad końcem epoki, której terminus ad quem stanowiły ustalenia w Rydze w marcu 1921 roku. I tu analogie z Wojna i sezonem Pawlikowskiego są bardzo wyraźne, albowiem autorka Czasu odmienionego także pisze o ostatecznym pożegnaniu z domem dzieciństwa i młodości. Z domem - „placówką" polskości na mińskiej ziemi.

I Czarnyszewicz, i Pawlikowski, i Lednicki (w mniejszym stopniu Czapska) to pisarze zrośnięci od pokoleń z Mińszczyzną. Inny był los Zofii Bohdanowiczowej, która przybyła na Wileńszczyznę już jako osoba dojrzała. Zrosła się z nią jednak równie silnie jak „tutejsi”, czego dowodzi zarówno tom wierszy poświęconych „ziemi miłości” (pod takim tytułem ukazał się w roku 1954 tomik jej wierszy poświęconych Wileńszczyźnie), jak i powieść Gwiazdy i kamienie wydana sześć lat później, w 1960 roku.

Dokładnie pół wieku po opublikowaniu Nadberezyńców Czesław Miłosz wydał zbiór esejów zatytułowanych Szukanie ojczyzny, będący swoistym zamknięciem emigracyjnego nurtu literatury poświęconej historycznemu Wielkiemu Księstwu Litewskiemu. Zamknięciem w kilku wymiarach. Szkice powstawały, co prawda, w kalifornijskim domu poety, na przełomie lat 80 . i 90. ubiegłego stulecia, ale opublikowane zostały już w Polsce wolnej w roku 1991. Wydane zostały, z szerszej perspektywy, już w Europie postsowieckiej, w świecie przezwyciężonego porządku jałtańskiego ${ }^{4}$, co oznaczało powrót na mapy niepodległej Litwy i powstanie suwerennej Białorusi, o której marzyli, mitygowani wszakże przez Polaków, białoruscy bohaterowie powieści Czarnyszewicza. Najważniejszy jednak wymiar zawiera się

\footnotetext{
${ }^{4}$ Oznaczało to także przezwyciężenie porządku poryskiego. Traktat z roku 1921, który przepołowił Białoruś na część polską i sowiecką, dla pisarzy pokolenie starszych od Miłosza, wychowanych na ziemiach Wielkiego Księstwa, stanowił równe ważną cezurę, jak układ jałtański. Można powiedzieć więcej - dał początek procesowi, którego zwieńczeniem stał się podział Europy uzgodniony w Jałcie.
} 
w akceptacji tego właśnie porządku politycznego, a więc przekroczenia, jak mówi Miłosz, „polskiej ortodoksji” (Miłosz 2001, 13), szczególnie żywej wśród „niezłomnej” emigracji, dla której teza, że w dalszym ciągu „istnieją: Korona i sfederowane z nią Wielkie Księstwo Litewskie" (Pawlikowski 2010, 346), była niepodważalnym dogmatem. Otóż eseje Miłosza dowodzą, że możliwe jest przecież przekroczenie etnocentrycznego zapętlenia. $\mathrm{W}$ takim ujęciu stają się próbą znalezienia „tkanki łącznej” w przestrzeni, w której niepodzielnie zdają się panować „narodowe lojalności” (Miłosz 2001, 14).

Akcja Nadberezyńców rozgrywa się w zaściankach szlacheckich położonych niedaleko Bobrujska, w klinie Berezyny i Dniepru, zatem na ziemiach utraconych przez Rzeczpospolitą Obojga Narodów w II rozbiorze. Bobrujsk, w którym w czasach Czarnyszewicza mieszkała stosunkowo niewielka liczba Polaków, stanowi też centrum świata Wicika Żywicy. W ostatniej powieści, w Chłopcach z Nuwoszyszek, pisarz, odzwierciedlając porządek własnego doświadczenia biograficznego, przenosi akcję do wsi położonych niedaleko Lidy, aby na koniec doprowadzić bohaterów do Wilna i siół podwileńskich. Bobrujsk pozostaje więc w świadomości powieściowych postaci Czarnyszewicza (i jego samego) tym miastem najbliższym, utraconym i wytęsknionym. Nie jest to wszakże najdalej na wschód wysunięty przyczółek polskości w dziełach nurtu białoruskiego. U samej wschodniej granicy jeszcze XVII-wiecznej Rzeczypospolitej, przy „Bramie Smoleńskiej”, po sąsiedzku z Katyniem, znajdował się majątek Borek, do którego przenosi się wspomnieniami Wacław Lednicki. I jest to jedyne miejsce w polskich utworach „białoruskich”, które leżało poza granicami przedrozbiorowymi. Zasadniczo inna w stosunku do Nadberezyńców i Wicika Żywicy przestrzeń Chłopców z Nuwoszyszek bliska jest natomiast światu powieści Bohdanowiczowej Gwiazdy i kamienie, której akcja rozgrywa się głównie we wsi Kamionka nad Mereczanką (w obecnym obwodzie solecznickim na Litwie), ale także w Wilnie i na Żmudzi. Jest to już zatem Wileńszczyzna, a nie Mińszczyzna, a więc ziemie III rozbioru, które zostały przywrócone II Rzeczypospolitej. Ale jest to ta część Wileńszczyzny, co dla rozważań na temat relacji polsko-białoruskich ma znaczenie fundamentalne, w której Litwinów niemal w ogóle nie było. Jest to ta ziemia, która - jak w wierszu Przychodzi poeta pięknie pisał Stanisław Baliński - „wzdycha po białorusku i po polsku śpiewa" (Baliński 1982, 157).

$\mathrm{W}$ pasie ziemi ograniczonym $\mathrm{z}$ jednej strony Berezyną $\mathrm{z}$ drugiej Dnieprem akcję swojej powieści umiejscowił Pawlikowski. Ale rangę „pierwszego" miasta bohatera uzyskuje Mińsk. Autor Wojny i sezonu nie ogranicza się wszakże do guberni mińskiej, opisuje także gubernię mohylowską, z najdalej na wschód położonym centrum polszczyzny w Bielicy, opisuje gubernię wileńską, nieco mniej witebską. Jest to zawsze Białoruś „pańska”, której prezentację umożliwiają autorowi wspomnienia wizyt w rozrzuconych po niej dworkach i pałacach „obywatelstwa” oraz znacznie rzadsze odwiedziny „okolic” szlacheckich. Brakuje w gawędach Pawlikowskiego 
tych, którzy stanowili „sól ziemi” białoruskiej, brakuje chłopów. A przecież w Dzieciństwie i młodości... jednoznacznie stwierdził, że w guberni mińskiej mieszkało bez mała trzy miliony chłopów mówiących po białorusku i trzysta tysięcy szlachty zagrodowej, więc Polaków. A może „tutejszych”? Ich nieobecność na kartach książek Pawlikowskiego zniekształca więc obraz Białorusi i bardzo poważnie go zubaża.

Podobnie zamknięta w świecie arystokratycznym pozostaje Czapska. "Od kraju naszego i jego ludu” odcinały ją, o czym pisze ze smutkiem, „przegrody surowego wychowania” (Czapska 1989, 201). Ukształtowana lekturami polskich i rosyjskich pisarzy „socjalnaja bol” otwierała oczy na „nierówności społeczne” (Czapska 1989, 245). Skłaniała do refleksji nad życiem białoruskich chłopów, ale nie dawała szansy wglądu. Ze światem pisarzy „nadberezyńskich”, Czarnyszewicza i Pawlikowskiego, podmiński świat Czapskiej łączy to, że po traktacie ryskim, zarówno jeden, jak i drugi znalazły się poza granicami II Rzeczypospolitej.

$\mathrm{Na}$ Polesiu wychował się „leśnik”, tytułowy bohater powieści Kuncewiczowej. Polesie to także świat „trylogii” łowieckiej Franciszka Wysłoucha. Jego opowieści wiążą się z puszczami i ostępami Pińszczyzny. Stanowią najpiękniejszy hołd dla tej ziemi, a jednocześnie zakwestionowanie ówczesnych przekonań, że Pińszczyzna to „biedny i smutny kraj”. Romantyczności poleskiej poświęca też sporo serdecznych słów autor Wojny i sezonu, może nawet bardziej zapalony łowiec niż Wysłouch.

Historyczne spektrum „białoruskiego nurtu” w prozie emigracyjnej rozciąga się od Powstania Styczniowego aż po koniec Niepodległej, aczkolwiek Mackiewicz w Nie trzeba głośno mówić przedłuża je po czasy okupacji hitlerowskiej na ziemiach białoruskich. W Lewej wolnej na białoruskich głównie ziemiach umieszcza teatr wojny polsko-bolszewickiej 1919-1920 roku. Do wszystkich niemal książek przywołanych w niniejszym szkicu można zastosować niezwykle trafne słowa Pawlikowskiego z recenzji Europy w rodzinie, w której podkreślał on, że dzieło Czapskiej jest „nie tylko «małą» historią rodzinną wplecioną w Wielkie Dzieje, ale przede wszystkim bogatym i żywo napisanym materiałem do tych Wielkich Dziejów" (Pawlikowski 1971, 2).

Bo rzeczywiście w większości książek nurtu białoruskiego Wielkie Dzieje determinują losy ludzkie w tej mało znanej części Europy, raz po raz niszczonej wojnami i rewolucjami, kaleczą je i wypaczają. Różne momenty historyczne przykuwają uwagę pisarzy. Najdalej w przeszłość, poza Czapską, sięga Bohdanowiczowa, ale dla jej bohaterów najważniejszym wydarzeniem pozostaje Powstanie Styczniowe. Ten zryw i jego straszne konsekwencje, w tym polaryzacja stanowisk wobec powstania, wyzwoliły w "tutejszych" nieśmiałe jeszcze próby określenia własnej tożsamości, zmusiły do postawienia pytania - kim jestem. W powieściowych retrospekcjach, poszukując wzorów społecznego modus vivendi, sięga Bohdanowiczowa nawet czasów panowania Stanisława Augusta, kiedy ksiądz Paweł Brzostowski uwolnił chłopów od pańszczyzny i stworzył Rzeczpospolitą Pawłowską. Szczęśliwym 
zamknięciem tej trudnej i dramatycznej epoki staje się wejście wojsk polskich do podwileńskiej wsi, spełnienie marzeń i oczekiwań tamtejszych Polaków.

Dla Czarnyszewicza, który historie opowiedziane w trzech „białoruskich" powieściach umieszcza w dekadzie 1911-1922, absolutnie najważniejsze znaczenie uzyskuje walka o włączenie w granice niepodległego państwa polskiego zaberezyńskich aż po Dniepr rubieży przedrozbiorowej Rzeczypospolitej. Przy tej okazji pisarz kreśli niezwykle sugestywnie narodowe i kulturowe, ale także społeczno-historyczne tło owej walki. Przedakcja tego zasadniczego wątku obejmuje w Nadberezyńcach „małą historię” polskiego zaścianka i jego mieszkańców, ich konflikty z białoruskimi mużykami, rewelacyjną rekonstrukcję codzienności zagrodowej szlachty, troskę o utrzymanie narodowej tożsamości i wiary katolickiej w ostatnich latach cesarstwa rosyjskiego. Wraz z rosyjską rewolucją historia nabiera gwałtownego przyspieszenia. Czarnyszewicz umiejętnie włącza „małą historię” w Wielkie Dzieje, odtwarza agitację bolszewicką, pogromy zaścianków, niemiecką okupację ziem zaberezyńskich, pobyt w Bobrujsku I Korpusu gen. Dowbora-Muśnickiego, nadzieje na niepodległość, wreszcie walkę z bolszewikami. W tej pierwszej powieści zabrakło jeszcze problemu, który zdominuje kolejne dzieła, czyli poszukiwania dróg porozumienia z Białorusinami, sojuszu w walce o wolną i sprawiedliwą Rzeczpospolitą.

W Dzieciństwie i młodości Tadeusza Irteńskiego Pawlikowskiego czytelnik otrzymuje panoramę Rosji za panowania Mikołaja II, do wybuchu I wojny światowej, przedstawioną z perspektywy zasadniczo prorosyjskiego Polaka. Są tu wydarzenia niezwykle ważne, które wstrząsnęły imperium Romanowów, ale także wydarzenia głęboko poruszające ówczesną inteligencje i „obywatelstwo” polskie, dziś już raczej zapomniane, jak na przykład włączenie w roku 1912 guberni chełmskiej (z ziem guberni siedleckiej i lubelskiej), wyłączenie jej trzy lata później z Kraju Nadwiślańskiego i przyłączenie do imperium, co odbierano wówczas jako kolejny rozbiór. W „cywilnej” historii Pawlikowskiego znajdzie się miejsce i na nastroje Polaków po manifeście ks. Mikołaja Mikołajewicza, i na klęski rosyjskie, i na niemiecką okupację tzw. „Ober-Ostu”, i na rewolucję rosyjską, i postawę wsi białoruskiej, i wreszcie polską tromtadrację. Wszystko to jednak przedstawia pisarz z perspektywy człowieka rozgoryczonego konsekwencjami przemian politycznych, traktatem ryskim i oddaniem Mińszczyzny bolszewikom. O tych samych wydarzeniach, z innej wszakże perspektywy, pisze rówieśnica Pawlikowskiego - Czapska. Ale poprzedza je, rekonstruując z dokumentów niezwykłą genealogię swojego rodu, sugestywną wizją epoki jeszcze przedrozbiorowej.

$\mathrm{Na}$ takim historycznym tle polscy pisarze emigracyjni umieszczają wydarzenia ostatnich siedemdziesięciu lat z wielowiekowego życia Polaków (lub spolonizowanych Białorusinów) na ziemiach białoruskich. Z polskiej perspektywy, dominującej w prozie emigracyjnej, było to więc pożegnanie z „krajem lat dziecinnych”, ze „źródłem, z którego pił Mickiewicz” 
(Pawlikowski 1946, 25). Były to ważne dla potomności zapisy polskiego życia, „odległego o stulecie, a może i o dwa” (Wańkowicz 1987, 5) od polskiej rzeczywistości powojennej, dokonane przez ostatnich świadków tamtego życia, potomków Rzeczypospolitej Obojga Narodów. Ale na pewno nie tylko ten aspekt decyduje o niezwykłym znaczeniu nurtu białoruskiego w polskiej prozie emigracyjnej. Przynajmniej kilku z jego twórców (Czarnyszewicz, Bohdanowiczowa), dzięki zakorzenieniu w realnym świecie polsko-białoruskim, dało świadectwo wyłaniania się narodu białoruskiego z chłopskich mas, odzwierciedliło proces zyskiwania przez Białorusinów własnej tożsamości. Wyrwało się z „pańsko-polskiego” horyzontu poznawczego, przekroczyło próg postfeudalnego, w najlepszym razie patriarchalnego stosunku pana do poddanego.

W zakończeniu Leśnika Marii Kuncewiczowej główny bohater powieści, syn mieszanego małżeństwa (ojciec Polak, matka z niemieckiego ojca i „tutejszej” matki) na pytanie, kim jest, odpowiada: „tutejszy” (Kuncewiczowa 1977, 154). Odpowiedź ta wydaje się efektem kolejnych rozczarowań postawą Polaków. „Leśnik”, który chciał stać się Polakiem, ale równie dobrze mógł zostać Rosjaninem, bo jeszcze nie Białorusinem, świadomie dokonuje takiego wyboru. Daje mu ów wybór poczucie pewnego bezpieczeństwa, nawet jeśli oznacza zasadniczą degradację społeczną w tej skomplikowanej narodowo i politycznie rzeczywistości. Przekroczenie progu bezpiecznej „tutejszości” wymaga zatem, jak sugeruje Kuncewiczowa, zaktywizowania odwagi, w znacznie większym stopniu niż świadomości. Pisarka świetnie wykazuje, że "tutejsi” to wcale nie zawsze białoruscy chłopi, że tutejszość może być także wyborem. Co ciekawe - o „tutejszości” piszą głównie twórcy, którzy - żyjąc w tym świecie białorusko-polskim - jakby nie w pełni się z nim zżyli i pozostawali obok (Czapska), albo jeszcze nie w pełni weń wrośli (Bohdanowiczowa), albo patrzą nań z boku (Kuncewiczowa). Zawsze jednak wynika to z pewnego dystansu wobec opisywanego świata. Najbardziej „tamtejszy” pisarz, Florian Czarnyszewicz, który może być traktowany jak polska „sól” białoruskiej ziemi, nie pisze o „tutejszych”. Nie poddaje się jednak pragnieniu narodowej idealizacji. Pisze o Polakach świadomych swojej narodowości, pisze o Polakach zbiałoruszczonych, pisze wreszcie o Białorusinach. Pokazuje, jak wielką rolę w procesie utraty poczucia polskości odgrywało odchodzenie od katolicyzmu, przejście na wiarę prawosławną. Przestawał bowiem działać najprostszy, aczkolwiek bardzo zawodny sposób odróżnienia Polaków od Białorusinów, wyznanie. Można by powiedzieć, że będąc w tym świecie wychowany i „zanurzony”, Czarnyszewicz potrafił i miał odwagę dookreślić narodowo nawet tych, którzy się przed tym wzbraniali. Pisarz marzył bowiem o Rzeczypospolitej wielonarodowej, którą stworzą wolne narody w pełni świadome swojej odrębności, w pełni odpowiedzialne za dobro kraju.

Pewne podobieństwa można odnaleźć w powieści Gwiazdy i kamienie, której głównym tematem uczyniła Bohdanowiczowa problem rodzenia się 
poczucia narodowej tożsamości pośród „tutejszych”. Z korzyścią dla struktury powieści i jej atrakcyjności splotła autorka ów problem z wątkiem erotycznym, osłabiając wszakże kwestię rodzenia się pytania o tożsamość. Miłość „tutejszej” chłopki do panicza, Polaka-powstańca, który wzniecał w niej uczucie nieznanego wcześniej patriotyzmu, rodzi w niej miłość do Polski, przekonanie o jej lepszości, o wyższości polskiego, „pańskiego”, języka nad językiem „mużyckim”. Z „tutejszej” stała się duchowo Polką. Ważne jest wszakże, iż Bohdanowiczowa na tym nie poprzestaje, kreuje także sytuację odwrotną. Otóż ta sama dziewczyna jest obiektem miłości chłopa, późniejszego męża dziewczyny. I ta właśnie miłość, podminowana zazdrością o miejsce Polaka w duszy żony, ale także nieuświadamianą z początku motywacją klasowo-narodową, każe mu z przekorą odrzucać wszystko, co polskie, i afirmować „swoje”, „tutejsze”, białoruskie. Synowie z tego małżeństwa pójdą różnymi drogami - dwaj z nich staną się świadomymi Polakami, najstarszy zaś, wierny naukom ojca, potwierdzenie swojej białoruskiej tożsamości znajdzie w białoruskich książkach rozprowadzanych przez polską dziedziczkę, marzącą o wspólnym państwie wszystkich narodów Rzeczypospolitej. Bohdanowiczowa świetnie uchwyciła znaczenie poezji Janki Kupały w procesie budzenia się narodowej świadomości po rewolucji 1905-1907. Kończy autorka powieść w duchu wielonarodowego solidaryzmu, odwołującego się do idei jagiellońskiej, który symbolizują drzewa rosnące na cmentarzu, gdzie pochowani zostali skłóceni narodowo małżonkowie. Jest to jednak raczej projekcja marzenia, które nie przesłania krytycznego spojrzenia Bohdanowiczowej na stosunek polskiej administracji do mniejszości białoruskiej.

W eseju poświęconym Europie $w$ rodzinie Konstanty Jeleński świetnie wychwycił przełomowe znaczenie roku 1905 dla Europy Środkowo-Wschodniej, który według niego stanowi „historyczny dział wód” (Jeleński 1989, 270). Do rangi symbolu owego działu urasta w książce Czapskiej opowieść o reakcji jej babki na widok tłumu chłopów białoruskich, żyjących w sąsiedztwie ziemiańskich Przyłuk, z których żaden, po roku 1905, nie zdjął przed nią czapki. Historia ruchów społecznych, przez kilka pokoleń właściwie na tych ziemiach niezmienna, nabrała gwałtownego przyspieszenia. Zwierzęcą zaciekłością, zwłaszcza dziesięć lat później, w roku 1917, odpowiedzieli mużyki za wielowiekową tresurę. Czasy rewolucji rosyjskiej i wojny polsko-bolszewickiej i dla Czarnyszewicza stały się najważniejszym momentem w procesie zyskiwania przez Białorusinów świadomości narodowej. Wtedy właśnie Białorusini, poddani z jednej strony ideologicznym naciskom bolszewików, z drugiej zaś „federacyjnym” zachętom przez Polaków, podjęli wysiłek nie tylko bycia narodem, ale także próbę stworzenia własnego państwa. I Czarnyszewicz takie postawy przypomina właściwie w każdej powieści, najpełniej chyba w Chłopcach z Nuwoszyszek. Jego znaczenie zawiera się jednak w tym, że pokazuje pełne spektrum stosunku białoruskiego chłopstwa do rzeczywistości historycznej, do jego różnych 
panów. Nie wolno ograniczać tego pisarza tylko do roli genialnego malarza-prymitywisty, który w nadberzyńskim fresku ocalił od zapomnienia i zaginięcia świat zaścianków i „okolic” szlacheckich porozrzucanych pomiędzy Berezyną i Dnieprem. W jego powieściach dominuje bowiem raczej problem polsko-białoruskiego współżycia na wspólnej ziemi, najpierw w granicach imperium Romanowów, potem, jak pięknie mówi jeden z bohaterów Wicika Żywicy, w epoce „wzięcia w rachubę woli obu narodów”.

Maria Czapska jako jedyna spośród pisarzy emigracyjnych nie tyle zwraca uwagę na kolonizacyjny charakter polskiej obecności na ziemi białoruskiej, ile tak właśnie tę obecność nazywa. Emocjonalnie boleje nad utratą domu, ale rozumie sytuację Białorusinów jako narodu poddanego kolonizacji i polonizacji. Akcentuje ogromne straty, jakie poniosła kultura białoruska wskutek spolonizowania wielkich rodów. Czapska nie mówi wprost, ale implicite sugeruje, że negatywnymi, nie tylko z perspektywy białoruskiej, konsekwencjami procesu polonizacji stało się ograniczenie narodu białoruskiego tylko do ciemnych mas chłopskich. Wskazuje jednak również przejawy „przebudzenia”, wspomina bowiem oburzającą „obywatelstwo” polskie postawę Romana Skirmunta i Edwarda Woyniłłowicza, którzy nie opowiedzieli się za przyłączeniem Białorusi do Rzeczypospolitej, ale za niepodległą Białorusią. Ich postawa, wtedy niezrozumiała i niepatriotyczna, pomogła Czapskiej w uświadomieniu, że Białorusini to naród, który walczy o swoje prawa, o swoje państwo i do którego przyznają się najwięksi z wielkich, choć bardzo nieliczni spośród ówczesnego „obywatelstwa”. W ujęciu Pawlikowskiego, idealizującego relacje między polskimi „panami” i białoruskim chłopstwem, pojedynczy przypadek odnotowany przez Czapską stanowi właściwie regułę. Autor Dzieciństwa i młodości... pokazuje ziemian rozmawiających z chłopami po białorusku, znających ludowe przyśpiewki, sprośne wierszyki. Znajomość folkloru, jak powiada autor, była w dobrym tonie. Pisze o pięknie ówczesnej białoruszczyzny w zestawieniu z językiem poddanym późniejszym sowieckim zabiegom. Nie ukrywa jednakże nadrzędnego celu takiej postawy, uczciwie zauważa polski, narodowy sens kultywowania języka białoruskiego. Stanowiła ona bowiem dla polskiego „obywatelstwa” najlepsze zabezpieczenie przed rusyfikacją. Poza pojedynczymi wyskokami zendeciałych indywiduów nikt, jak dowodzi autor Dzieciństwa i młodości..., nie prowadził polonizacji. Wykreowana przez Pawlikowskiego wizja ziem białoruskich jako świata wolnego od konfliktów narodowych, nawet społecznych, w którym Polacy, zarówno ci z dworów ziemiańskich, jak i zaścianków, żyli niemal w rodzinnej symbiozie z Białorusinami, znacznie jednak odbiega od obrazu „codziennej” Mińszczyzny w pozostałych utworach nurtu białoruskiego.

Konsekwencje spolonizowania pokazał Czarnyszewicz w Wiciku Żywicy. Białoruscy chłopi nie mają świadomości tego procesu, ale widzą jego efekty. Porównują się z Ukraińcami, których uważają za naród ciemniejszy od siebie, ale z podziwem podkreślają ich walkę o prawa, o własne 
państwo. Zazdroszczą im wodzów obdarzonych władzą zwołania i pociągnięcia za sobą mas. Czarnyszewicz przygotowuje jakby fundament pod manifestację białoruskiego jestestwa. Pod koniec powieści najbardziej uświadomiony narodowo białoruski bohater wszystkich utworów Czarnyszewicza, w pięknych, chyba nawet zbyt pięknych słowach deklaruje: „Miłość ziemielki rodzimej mnie wychowała, a praca uczciwa wykształciła. Znam gruntownie krzywdy nasze chłopskie i prawa, ale umiem odróżnić Prawdę od Kłamstwa" (Czarnyszewicz 1953, 251). Do tej samoświadomości prowadził Czarnyszewicz swoich białoruskich pobratymców przez dziesięć lat, w których zamyka się czas fabuły jego powieści. Ale sam do tego dojrzewał znacznie dłużej.

Z pewnością jego kolejne powieści tracą na wartości artystycznej. Podejmując pisanie kolejnych dzieł, miał już pisarz świadomość wypełnienia pierwszego, głównego swego posłannictwa: uwiecznienia piękna utraconej ziemi nadberezyńskiej i wysiłków jej mieszkańców o przyłączenie jej do Niepodległej Rzeczypospolitej. Miał prawo czuć gorycz i ból tą Wskrzeszoną, która nie tylko „nie objęła ich ziemi” i nie zadbała należycie o swoje „dzietki” przez wieki broniące polskości na najdalszych krańcach dawnej Rzeczypospolitej Obojga Narodów, ale przede wszystkim potraktowała ich jak „pasierbów” i zmusiła do wyjazdu, do poszukiwań pracy i chleba za oceanem. Niepowodzenie misji na białoruskich ziemiach, podział ich pomiędzy Polskę i Związek Sowiecki wywołał u Czarnyszewicza tę właśnie troskę o przyszłość relacji polsko-białoruskich. Pokazał więc pisarz, co jest niewątpliwie jego wielkim osiągnięciem, proces przezwyciężania narodowych wrogości, przenoszenia uczuć niechęci i nienawiści z poziomu etnicznego na poziom ogólnoludzki. Wicik Żywica powstawał w czasie, gdy ostateczne ustalenia zapadły, gdy okazało się, że niemal wszyscy Białorusini znaleźli się w państwie sowieckim. Wówczas silnie odezwały się w pisarzu pragnienia, utopijne wizje państwa, w którym oba narody połączy „związek braterski”, w którym zapanuje „wolność i równość prawdziwa”. Czarnyszewicz jako jedyny bodaj pośród polskich pisarzy nurtu białoruskiego uczciwie zwraca uwagę na marzenia Białorusinów o stworzeniu własnego państwa. Jego kolejne powieści dokumentują ewolucję myślenia twórcy o niepodległości pobratymczego narodu. Jeszcze w Nadberezyńcach z roku 1942 dowodził, że na wsiach białoruskich nad Berezyną myśl o suwerenności państwowej Białorusi wcale nie istniała, ale w późniejszym o dziesięć lat Wiciku Żywicy umieścił ważną deklarację: „Białoruś też ma prawo być i rządzić się sama sobą. (...) Tutaj naszej woli musi być posłuch. Tu nie Polska, a Białoruś" (Czarnyszewicz 1953, 196). Wszakże pojawienie się w powieściach Czarnyszewicza możliwości „wybicia się” Białorusi na niepodległość nie oznacza w żadnym razie jej bezwzględnej akceptacji. Ważne wydaje się samo uznanie przez pisarza zasadności żądań, dopuszczenie białoruskiego prawa do głosu. Nie pozostawia go jednak autor Wicika Żywicy bez dyskusji. Przywołuje różne argumenty uzasadniające prawo Polaków do życia na 
ziemiach białoruskich bez żadnego zaproszenia. Sięga do historii, do prapoczątków wspólnego losu. Sięga też pisarz do historii bliższej, do wspólnego życia pod berłem Romanowów. Czarnyszewicz nie poprzestaje jednakże na szukaniu racjonalnych czy logicznych argumentów, kreuje takich bohaterów, którzy potrafią dostrzec i zaakcentować zasadnicze podobieństwa między pobratymczymi ludami, ale też w pełni zrozumieć zagrożenie rusyfikacją. Podobieństwo mowy i obyczajów z jednoczesną wspólnotą niedoli okażą się najlepszym argumentem w szukaniu sojusznika do wspólnej walki ze wspólnym wrogiem. Odpowiedzią Czarnyszewicza na białoruski dylemat - związać się z „pańską” Polską czy przyłączyć do „kraju raboczych” - stała się więc „socjalna” idea jagiellońska, czyli wielonarodowa i socjalistyczna, ale nie bolszewicka, Rzeczpospolita. Krach owej idei, skutki obustronnej bezmyślności i braku woli wspólnego działania pokazał pisarz w dwóch ostatnich powieściach.

Autor Wicika Żywicy, ukazując codzienność polsko-białoruskiego współżycia na wschodnich rubieżach przedrozbiorowej Rzeczypospolitej w momencie przebudzenia świadomości narodowej Białorusinów, podjął refleksję nad różnymi, możliwymi sposobami jej wykorzystania z korzyścią dla obu narodów. I trafne było, jak się wydaje, poszukiwanie przez Czarnyszewicza społecznej podstawy wspólnych działań. Płaszczyzna etniczna, mimo zasadniczego podobieństwa języka i zwyczajów, oddzielała od siebie dwa bliskie narody.

Nie wszyscy wszakże podzielali ten pogląd. Powieści Czarnyszewicza wywołały poważną dyskusję, w której główny udział przypadł pisarzom nurtu białoruskiego. Najostrzej zareagował Michał Pawlikowski, który zarzucił autorowi Wicika Żywicy „majaczenia” „na temat złowrogiej roli ziemiaństwa" (Pawlikowski 1953, 3). W recenzji tej odezwał się dotknięty ziemianin, potomek mińskiego „obywatelstwa”, obwinionego przez Czarnyszewicza o postawę antybiałoruską, która uniemożliwiła stworzenie na ziemiach nadberezyńskich sprawiedliwego państwa polskiego. Wydaje się jednak, że to Czarnyszewicz ma rację w tym sporze. Ograniczony z założenia w dziełach Pawlikowskiego obraz stosunków polsko-białoruskich zdaje się wynikać z wielkopańskości autora, z protekcjonalnego stosunku do istot, które - jak mówił za Buninem - „jeszcze się niezupełnie nauczyły chodzić mocno na tylnych nogach" (Pawlikowski 1965, 12). W dziełach swoich, wbrew rzeczywistości, wskrzeszał „stary dobry świat”, trwał w idealizującym wyobrażeniu „z szlachtą polską białoruski lud” i taki obraz świata, z niezwykłym zresztą mistrzostwem artystycznym przekazał potomności.

Traktat ryski stanowić miał w koncepcjach endeckich, przeciwnych federalistycznym założeniom Piłsudskiego (choć po inkorporacji Litwy Środkowej trudno przecież mówić o federacji), próbę takiego rozwiązania kwestii mniejszości w Polsce, które dawało szansę ich spolonizowania. 
Innych wariantów ułożenia relacji między Polakami a mniejszościami w Rzeczypospolitej polityka endecka nie przewidywała. I jakkolwiek gorzko to zabrzmi, Stanisław Grabski, przewodniczący polskiej delegacji w rozmowach pokojowych, miał trafną intuicję (albo wiedzę o stosunku Polaków do innych). Niepodległa Polska, o czym świadczy los ponad pięciomilionowej mniejszości ukraińskiej i los półtoramilionowej mniejszości białoruskiej, nie potrafiła inaczej rozwiązać kwestii narodów włączonych wraz z ich ziemiami do granic II Rzeczypospolitej. Piękna idea „wolnych z wolnymi i równych z równymi", powtarzana z takim zaangażowaniem przez bohaterów Czarnyszewicza, po ostatecznym ustaleniu w 1921 roku granic Wskrzeszonej, ustąpiła miejsca praktykom, za które - jak pisała Bohdanowiczowi - „cały naród musiał się wstydzić”.

\section{Bibliografia:}

Baliński Stanisław, 1982, Peregrynacje. Poezje wybrane 1928-1981, Hertz P. (wybrał i posłowiem opatrzył), Warszawa.

Czapska Maria, 1989, Europa w rodzinie, Warszawa.

Czapska Maria, 2006, „Pamiętniki” Wacława Lednickiego, w: Czapska M., Ostatnie odwiedziny i inne szkice, Jeleński K. Marynia (zamiast przedmowy), Kądziela P. (oprac.), Warszawa.

Czarnyszewicz Florian, 1953, Wicik Żywica, Buenos Aires.

Czarnyszewicz Florian, 1991, Nadberezyńcy, Lublin.

Jeleński Konstanty, 1989, Dział wód, w: Czapska M., Europa w rodzinie, Warszawa.

Kuncewiczowa Maria, 1977, Leśnik, Warszawa.

Mackiewicz Józef, 1994, Lewa wolna, Londyn.

Miłosz Czesław, 2001, Szukanie ojczyzny, Kraków.

Pawlikowski Michał Kryspin, 1946, Sumienie Polski. Rzecz o Wilnie i Kraju Wileńskim, Londyn.

Pawlikowski Michał Kryspin, 1953, Czarnyszewicz znad Berezyny i Wańkowicz z Żoliborza, „Wiadomości”, nr 24 (376), Londyn.

Pawlikowski Michał Kryspin, 1965, Wojna i sezon, Paryż.

Pawlikowski Michał Kryspin, 1971, „Europa w rodzinie”, „Wiadomości”, nr 7 (1298), Londyn.

Pawlikowski Michał Kryspin, 2010, Dzieciństwo i młodość Tadeusza Irteńskiego, Urbanowski M. (oprac. tekstu, przypisy i posł.), Łomianki.

Taylor-Terlecka Nina, 1986, Dziedzictwo W. X. Litewskiego w literaturze emigracyjnej, „Kultura”, nr 10 (469), Paryż.

Wańkowicz Melchior, 1987, Szczenięce lata, Kraków. 


\section{O Autorze:}

Tadeusz Sucharski, dr hab., profesor nadzwyczajny Akademii Pomorskiej w Słupsku, historyk literatury polskiej i rosyjskiej. Jego zainteresowania naukowe obejmują: literaturę polską Drugiej Emigracji, związki literatury polskiej z literaturą rosyjską, doświadczenie totalitaryzmu w literaturze, literaturę łagrową (polską i rosyjską), twórczość Dostojewskiego (przewodniczący polskiej sekcji International Dostoevsky Society), poezję dwudziestolecia międzywojennego. Autor książek: Dostojewski HerlingaGrudzińskiego (2002), Polskie poszukiwania „innej Rosji”. O nurcie rosyjskim $w$ literaturze Drugiej Emigracji (2008). Współredaktor tomów Przestrzenie lęku. Lęk w kulturze i sztuce XIX-XXI w (2006), Autobiografizm i okolice. (2011), Polska - Ukraina. Dziedzictwo i współczesność. Польща - Україна. Спадщина і сучасність (2012). Między rusofobia a rusofilia. Poglady, postawy i realizacje $w$ literaturze polskiej od XIX do XXI wieku (2016), Dostojewski i inni (2016), „Rozliczanie” przeszłości: relacje polsko-żydowskie w tekstach kultury XX i XXI wieku (2016). Autor ponad 100 prac naukowych; publikował w najważniejszych polskich pismach historycznoliterackich oraz w licznych pracach zbiorowych, także w Rosji, na Ukrainie, Białorusi, Węgrzech, Litwie, w Hiszpanii. Laureat prestiżowej Nagrody PAN im. Aleksandra Brücknera w dziedzinie literatury i filologii (2011) za książkę Polskie poszukiwania „innej Rosji”. 